\title{
Estimate of Peanut Production Function under Irrigated Conditions and Salinity
}

\author{
Ali Abdzad Gohari' ${ }^{1}$ Hossein Babazadeh ${ }^{1 *}$, \\ Ebrahim Amiri², Hossein Sedghi ${ }^{1}$ \\ ${ }^{1}$ Department of Water Science and Engineering, Science and Research Branch, Islamic Azad University, Tehran, Iran \\ ${ }^{2}$ Department of Agronomy, Lahijan Branch, Islamic Azad University, Lahijan, Iran
}

Received: 1 July 2017

Accepted: 3 September 2017

\begin{abstract}
Salinity is one of the main and common challenges in the world. This study was conducted to determine the effect of salinity and water requirements of peanuts, with main factors including water requirement $40 \%\left(\mathrm{WR}_{4}\right), 60 \%\left(\mathrm{WR}_{3}\right), 80 \%\left(\mathrm{WR}_{2}\right)$, and $100 \%\left(\mathrm{WR}_{1}\right)$; sub-treatment including salinity with values of $1\left(\mathrm{~S}_{1}\right), 3\left(\mathrm{~S}_{2}\right), 5\left(\mathrm{~S}_{3}\right)$, and $7\left(\mathrm{~S}_{4}\right) \mathrm{dS} / \mathrm{m}$; and sub-sub-treatment including four cultivars Guil $\left(\mathrm{V}_{1}\right)$, Gorgani $\left(\mathrm{V}_{2}\right)$, Jonobi $\left(\mathrm{V}_{3}\right)$, and Mesri $\left(\mathrm{V}_{4}\right)$. The experimental design was conducted in the form of split factorial in a completely randomized block with 3 replications in 2015 and 2016. The results showed that the maximum seed yields in salinity levels of $1 \mathrm{dS} \mathrm{m}^{-1}$ in 2015 and 2016 were 1,142 and $987 \mathrm{~kg} \mathrm{ha}^{-1}$, respectively. On the interaction effect of irrigation and salinity, maximum seed yields in $80 \%$ water requirement and salinity of $1 \mathrm{dS} \mathrm{m}^{-1}$ in 2015 and 2016 were 1,393 and 1,265 $\mathrm{kg} \mathrm{ha}^{-1}$, respectively. The maximum seed yields in Jonobi cultivar with salinity of $1 \mathrm{dS} \mathrm{m} \mathrm{m}^{-1}$ and in Guil cultivar in salinity of $5 \mathrm{dS} \mathrm{m}^{-1}$ were 1,254 and $1,127 \mathrm{~kg} \mathrm{ha}^{-1}$, respectively. The Guil cultivar in 100\% water requirement and with salinity of $1 \mathrm{dS} \mathrm{m}^{-1}$ in 2015 and 2016 had the highest seed yield, with 1,883 and $1,710 \mathrm{~kg} \mathrm{ha}^{-1}$, respectively.
\end{abstract}

Keywords: irrigation, peanut cultivars, yield, water requirement

\section{Introduction}

The peanut is one of the most important and economic oil seeds in tropical and subtropical areas. It is rich in minerals, vitamins, fatty acids, fiber, and phenolic compounds [1-2]. It is also a good source of protein for humans and livestock, and it plays an important role in improving the fertility of soil by fixing atmospheric nitrogen [3]. In terms of climate, Iran is located in an arid and semi-arid region. Limited water resources and appropriate and scattered distribution of rainfall have

*e-mail: h_babazadeh@srbiau.ac.ir made it essential to use water efficiently and optimally in the agricultural sector. The importance of water is undeniable in the production of the peanut and it is essential in the colloidal structure of protoplasm and performing metabolic activities [4-5]. We examined the yield of peanut genotypes at different irrigation levels and have reported that seed yield is reduced significantly by reducing the number and volume of irrigation, so that the lack of irrigation in a peanut plant reduced $21 \%$ of seed yield per hectare compared to full irrigation conditions [3]. It is necessary to determine the exact water requirements of the peanut since we can improve water management for this plant [6].

The peanut is relatively tolerant against drought, and its roots have ability to absorb water from soil depths 
Table 1. Meteorological data.

\begin{tabular}{|c|c|c|c|c|c|c|c|c|c|c|}
\hline \multirow{2}{*}{$\begin{array}{l}\text { During } \\
\text { growth }\end{array}$} & \multicolumn{2}{|c|}{$\begin{array}{c}\text { Maximum } \\
\text { Temperature }\left({ }^{\circ} \mathrm{C}\right)\end{array}$} & \multicolumn{2}{|c|}{$\begin{array}{c}\text { Minimum } \\
\text { Temperature }\left({ }^{\circ} \mathrm{C}\right)\end{array}$} & \multicolumn{2}{|c|}{ Wind Speed $\left(\mathrm{m} \mathrm{s}^{-1}\right)$} & \multicolumn{2}{|c|}{$\begin{array}{c}\text { Minimum } \\
\text { Humidity (\%) }\end{array}$} & \multicolumn{2}{|c|}{$\begin{array}{c}\text { Maximum } \\
\text { Humidity (\%) }\end{array}$} \\
\hline & 2016 & 2015 & 2016 & 2015 & 2016 & 2015 & 2016 & 2015 & 2016 & 2015 \\
\hline May & 25.2 & 24.5 & 13.7 & 14.8 & 2.2 & 2.1 & 90 & 89 & 79 & 75 \\
\hline Jun & 27.3 & 28.4 & 17.3 & 18.4 & 1.2 & 2.4 & 92 & 90 & 55.5 & 58.9 \\
\hline Jul & 41.9 & 31.9 & 20 & 19 & 1.9 & 1.8 & 85.9 & 93.4 & 66.9 & 49 \\
\hline August & 29.5 & 28.9 & 18.8 & 20.2 & 1.3 & 2.9 & 95.4 & 89 & 71 & 61.9 \\
\hline September & 28.4 & 27.3 & 18.5 & 19.2 & 1.9 & 2.8 & 91.3 & 88 & 58 & 63.8 \\
\hline
\end{tabular}

[4]. Peanut cultivars show different reactions to water stress in different growth stages, and the value of water has a significant impact on the growth of pods. High soil moisture is required to develop peanuts at all stages of growth. However, under limited water conditions, irrigation scheduling in critical stages can increase yield and water use efficiency in peanut [4]. Salinity is one of the plants limiting stresses around the world, and achieving salt-tolerance is highly desirable in today's agricultural context [7-8]. Since most crop species are sensitive to salt, salinity has become a serious threat to agriculture, especially in arid, semi-arid, and coastal areas of world, because it limits plant growth and productivity [9-10]. Salinity is also one of the major problems that has made a large part of lands uncultivable. Approximately one third of the world's cultivable irrigated lands are affected by salinity, a rate that is rising [11]. Using saline water is one of the key strategies for optimizing the use of water, and this has high priority.

The peanut is relatively sensitive to soil and water salinity, and salinity reduces seed germination, growth, and dry matter production [11-12]. The production function is a purely physical concept and it simply shows the relationship between inputs and outputs of production. This function describes the maximum yield obtained by different combinations of inputs. Therefore, in this regard, we should think not only of product yield, but proper use of resources has greater importance. By estimating the agricultural production function and information obtained from it, we can determine the production capacity and compare it with actual yield. This comparison provides the conditions for identifying the major problems in this sector and comprehensive understanding of the main factors involved in it. Estimating the production function also makes it possible to determine the role and importance of production inputs separately.

The peanut is one of the most important plants in the northern Iran (Guilan Province), which determines water requirement, and identifying cultivars tolerant to salinity is very important in this plant. The objective of this study was to examine the efficiency of water use and to estimate the production function of peanut cultivar in different levels of salinity.

\section{Material and Methods}

The present experiment was conducted in northern Iran at latitude $37^{\circ} 25^{\prime}$ and longitude $49^{\circ} 94^{\prime}$, and with average height of $5 \mathrm{~m}$ above sea level in 2015 and 2016 in twice-split plots, and based on completely randomized blocks designed in 3 replications. The city is considered among the more mild and humid areas in terms of climate. Rainfall during the growing season in 2015 and 2016 was 232.8 and $349.6 \mathrm{~mm}$, respectively (Table 1). Before preparing the land, sampling was randomly performed from soil of different points of the farm at two depths: 0-20 and 20-40 cm (Table 2).

The time to sow seeds in both years was 10 May and harvest time was the 20 September. Each study subject had dimensions of $4 \times 2.5 \mathrm{~m}$ with 6 cultivation rows. In this study, the main factor was water requirements of $40\left(\mathrm{WR}_{4}\right), 60\left(\mathrm{WR}_{3}\right), 80\left(\mathrm{WR}_{2}\right)$, and $100\left(\mathrm{WR}_{1}\right)$ percent, and sub-treatment included salinity of levels $1\left(\mathrm{~S}_{1}\right), 3\left(\mathrm{~S}_{2}\right)$,

Table 2. Characteristics of soil in the study area

\begin{tabular}{|c|c|c|c|c|c|c|c|c|c|}
\hline \multicolumn{10}{|c|}{ Particle size distribution \% } \\
\hline $\begin{array}{c}\text { Crop } \\
\text { years }\end{array}$ & $\begin{array}{c}\text { Soil depth } \\
(\mathrm{cm})\end{array}$ & Sand & Silt & Clay & $\begin{array}{c}\text { Organic } \\
\text { Carbon }\end{array}$ & $\begin{array}{c}\text { Soil } \\
\text { texture }\end{array}$ & $\begin{array}{c}\text { Bulk density } \\
(\mathrm{g} \mathrm{cm})^{-3}\end{array}$ & $\begin{array}{c}\text { Permanent Wilting Point } \\
(\%)\end{array}$ & $\begin{array}{c}\text { Field Capacity } \\
(\%)\end{array}$ \\
\hline \multirow{2}{*}{2015} & $0-20$ & 49 & 32 & 19 & 0.68 & Loamy & 1.25 & 14.7 & 27.1 \\
\cline { 2 - 11 } & $20-40$ & 49 & 31 & 20 & 0.66 & Loamy & 1.33 & 14.2 & 28.5 \\
\hline \multirow{2}{*}{2016} & $0-20$ & 45 & 38 & 17 & 0.36 & Loamy & 1.25 & 14.7 & 27.1 \\
\cline { 2 - 11 } & $20-40$ & 45 & 38 & 17 & 0.30 & Loamy & 1.33 & 14.2 & 28.5 \\
\hline
\end{tabular}


Table 3. Amount of water use in each treatment in 2015 and 2016.

\begin{tabular}{|c|c|c|c|c|}
\hline Year & 2015 & 2016 & 2015 & 2016 \\
\hline $\begin{array}{c}\text { Water } \\
\text { requirements }\end{array}$ & \multicolumn{2}{|c|}{$\begin{array}{c}\text { Amount of irrigation } \\
(\mathrm{mm})\end{array}$} & \multicolumn{2}{|c|}{$\begin{array}{c}\text { Amount of water } \\
\text { use (mm) }\end{array}$} \\
\hline $40 \%$ & 108 & 121 & 340.5 & 470.6 \\
\hline $60 \%$ & 145 & 171 & 377.8 & 520.3 \\
\hline $80 \%$ & 163 & 202 & 395.5 & 551.3 \\
\hline $100 \%$ & 222 & 238 & 454.8 & 587.9 \\
\hline
\end{tabular}

$5\left(\mathrm{~S}_{3}\right)$, and $7\left(\mathrm{~S}_{4}\right) \mathrm{dS} \mathrm{m} \mathrm{m}^{-1}$, and sub-sub-treatment included four cultivars of peanut, including Guil $\left(\mathrm{V}_{1}\right)$, Gorgani $\left(\mathrm{V}_{2}\right)$, Jonobi $\left(\mathrm{V}_{3}\right)$, and Mesri $\left(\mathrm{V}_{4}\right)$. To determine the irrigation treatments, soil moisture discharge was used and water requirement of plant was considered as $100 \%$ irrigation treatment, and other irrigation treatments were considered as a percentage of this value. The duration and value of irrigation at each stage were determined with depth of the root and measuring the soil moisture using a weight method in the relevant layer at any stage of irrigation. Soil moisture in the root depth using Equation (1) was calculated for soil moisture to reach the capacity limit of the farm. The duration of irrigation was also calculated after reaching the water to moisture front in the plant root depth.

$$
d_{n}=\left(\Theta_{f c}-\Theta_{i}\right) \cdot \rho_{b} \cdot D_{r}
$$

...where: $\Theta_{\mathrm{fc}}:$ moisture at field capacity $(\%), \Theta_{\mathrm{i}}:$ moisture content in the soil $(\%), \rho_{\mathrm{b}}$ : bulk density $\left(\mathrm{g} \mathrm{cm}^{-3}\right)$, and $\mathrm{D}_{\mathrm{r}}$ : root depth $(\mathrm{cm})$. Measuring the amount of water delivered to every plot was performed by flow meters. The amounts of water during growing were obtained through irrigation and rainfall (Table 3).

To determine the yield in each plot, after removing two rows from both sides, 12 plants were randomly selected and placed within the oven at a temperature of $70^{\circ} \mathrm{C}$ for 48 hours. After drying, the samples were weighed with one hundredth of a weight precision scale. In each plot, after deleting the rows from both sides, 12 plants were randomly selected. To determine the weight of 100 seeds, $200 \mathrm{~g}$ of pod was selected as samples, and 100 seeds were randomly selected and their weight was recorded by a scale $(\mathrm{g})$. To determine the length of seed in each plot, 50 seeds were randomly selected and they were measured by a caliper. To determine the height of plants, 12 plants were randomly selected from each plot and they were measured by a ruler. Product yield may be written as a function of water and salinity. When the production function is expressed in the form of an equation, the optimal value of function variables can be determined. To determine the production function in the form of a two-variable function, yield data against water and salinity were ordered. The best fit of used-yield

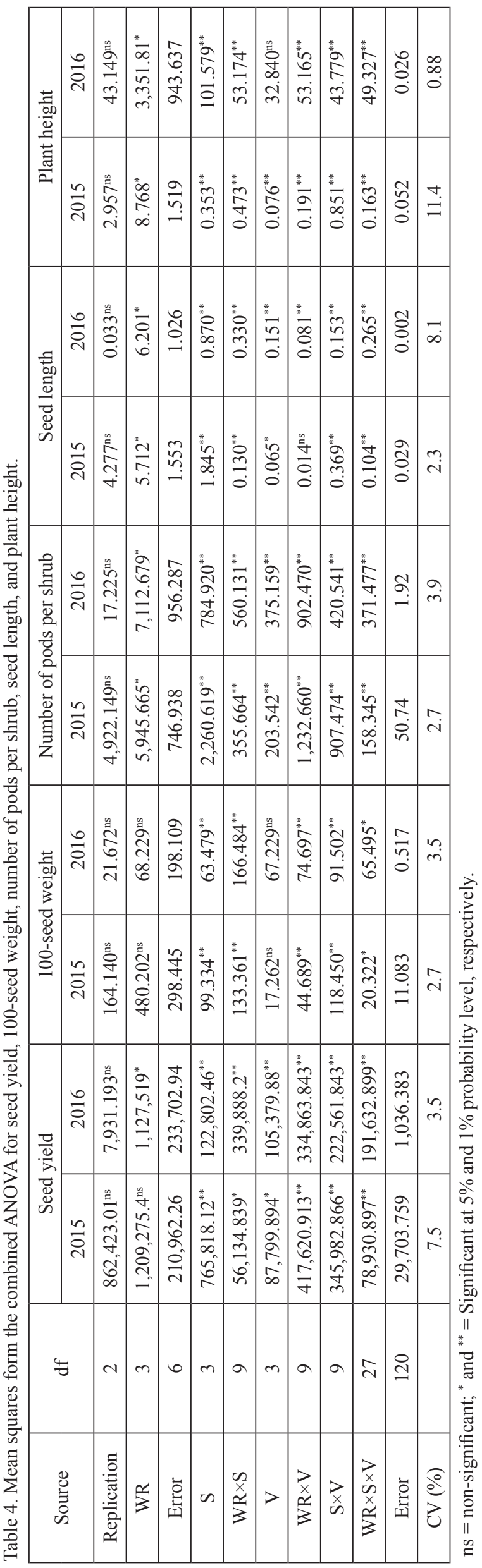


Table 5. Mean comparison of the effects of WR and S treatments on parameters of seed yield, 100-seed weight, number of pods per shrub, seed length, and plant height.

\begin{tabular}{|c|c|c|c|c|c|c|c|c|c|c|}
\hline \multirow[t]{2}{*}{ Treatments } & \multicolumn{2}{|c|}{$\begin{array}{l}\text { Seed Yield } \\
\left(\mathrm{kg} \mathrm{ha}^{-1}\right)\end{array}$} & \multicolumn{2}{|c|}{$\begin{array}{c}\text { 100-seed weight } \\
(\mathrm{g})\end{array}$} & \multicolumn{2}{|c|}{$\begin{array}{l}\text { Number of pods per } \\
\text { shrub }\end{array}$} & \multicolumn{2}{|c|}{$\begin{array}{l}\text { Seed length } \\
(\mathrm{cm})\end{array}$} & \multicolumn{2}{|c|}{$\begin{array}{l}\text { Plant height } \\
(\mathrm{cm})\end{array}$} \\
\hline & 2015 & 2016 & 2015 & 2016 & 2015 & 2016 & 2015 & 2016 & 2015 & 2016 \\
\hline $\mathrm{WR}_{1}$ & $1,052 \mathrm{a}$ & $1,032 \mathrm{ab}$ & $27 \mathrm{a}$ & $27 \mathrm{a}$ & $70 \mathrm{ab}$ & $68 \mathrm{ab}$ & $2.5 \mathrm{a}$ & $2.4 \mathrm{a}$ & $66.2 \mathrm{~b}$ & $64.9 \mathrm{ab}$ \\
\hline $\mathrm{WR}_{2}$ & $1,177 \mathrm{a}$ & $1,169 \mathrm{a}$ & $30 \mathrm{a}$ & $27 \mathrm{a}$ & $77 \mathrm{a}$ & $70 \mathrm{a}$ & $2.3 \mathrm{ab}$ & $2 \mathrm{ab}$ & $72.4 \mathrm{a}$ & $65.7 \mathrm{a}$ \\
\hline $\mathrm{WR}_{3}$ & $888 \mathrm{a}$ & $782 \mathrm{c}$ & $25 \mathrm{a}$ & $25 \mathrm{a}$ & $58 \mathrm{bc}$ & $49 b$ & $2 \mathrm{ab}$ & $1.6 \mathrm{~b}$ & $56.2 \mathrm{c}$ & $50.1 \mathrm{~b}$ \\
\hline $\mathrm{WR}_{4}$ & $827 \mathrm{a}$ & $791 b c$ & $23 \mathrm{a}$ & $25 \mathrm{a}$ & $53 \mathrm{c}$ & $47 b$ & $1.7 \mathrm{~b}$ & $1.7 \mathrm{~b}$ & $51.9 \mathrm{~d}$ & $51.6 \mathrm{ab}$ \\
\hline $\mathrm{S}_{1}$ & $1142 \mathrm{a}$ & $978 \mathrm{a}$ & $27 \mathrm{a}$ & $26 \mathrm{c}$ & $73 \mathrm{a}$ & $63 a$ & $2 b$ & $1.9 \mathrm{c}$ & $63.4 \mathrm{a}$ & $59.2 \mathrm{~b}$ \\
\hline $\mathrm{S}_{2}$ & $979 b$ & $906 \mathrm{c}$ & $24 \mathrm{~b}$ & $25 \mathrm{~d}$ & $66 \mathrm{~b}$ & $60 \mathrm{~b}$ & $2.4 \mathrm{a}$ & $2.1 \mathrm{a}$ & $60.5 \mathrm{c}$ & $56.9 \mathrm{c}$ \\
\hline $\mathrm{S}_{3}$ & $991 b$ & $932 b$ & $27 \mathrm{a}$ & $27 \mathrm{a}$ & $61 \mathrm{c}$ & $56 \mathrm{c}$ & $2 b$ & $1.9 \mathrm{~b}$ & $62.9 \mathrm{~b}$ & $59.5 \mathrm{a}$ \\
\hline S4 & $833 c$ & $857 d$ & $26 a b$ & $26 b$ & $57 d$ & $55 \mathrm{c}$ & $2 b$ & $1.8 \mathrm{~d}$ & $59.8 \mathrm{~d}$ & $56.7 \mathrm{~d}$ \\
\hline
\end{tabular}

salinity and water explaining the production function is as follows:

$$
\mathrm{Y}(w u, s)=a_{0}+a_{1} w u+a_{2} s
$$

...where $\mathrm{Y}$ is yield $\left(\mathrm{kg} \mathrm{ha}^{-1}\right)$, WU is the amount of water $(\mathrm{mm}), \mathrm{S}$ is salinity $\left(\mathrm{dS} \mathrm{m}^{-1}\right)$, and $\mathrm{a}_{0}$ and $\mathrm{a}_{1}$ are constants of the equation. Variance analysis and comparing the data were performed by MSTAT-C software, and production function coefficients were estimated by STATISTICA 5.5 software.

\section{Results and Discussion}

\section{Seed Yield}

The effect of irrigation on seed yield in 2015 and 2016 was significant at the probability level of 5\%. Salinity values' effects on seed yield were significant in 2015 and 2016 at a probability level of 5\%. The interaction effect of irrigation and salinity on seed yield was significant in 2015 at the probability level of $5 \%$, while the interaction effect of irrigation and salinity was significant in 2016 at the probability level of $1 \%$ (Table 4 ). The maximum seed yield in 2015 in treatment of $80 \%$ of water requirement was $1,169 \mathrm{~kg} \mathrm{ha}^{-1}$, respectively (Table 5). The maximum seen yield in 2015 and 2016 at salinity level of $1 \mathrm{dS} \mathrm{m}^{-1}$ was 1,142 and $978 \mathrm{~kg} \mathrm{ha}^{-1}$, respectively (Table 5). Seed yield in 2015 and 2016 in treatment of $80 \%$ of the water requirement and salinity level of $1 \mathrm{dS} \mathrm{m} \mathrm{m}^{-1}$ was 1,393 and $1,265 \mathrm{~kg} \mathrm{ha}^{-1}$, respectively (Table 6). The effect of peanut cultivars on seed yield in 2015 was significant at the probability level of $5 \%$, while it was significant at the probability of $1 \%$ in 2016 (Table 4). The yield in the Guil cultivar was $1,008 \mathrm{~kg} \mathrm{ha}^{-1}$ in 2015 , and in the Jonobi cultivar $970 \mathrm{~kg} \mathrm{ha}^{-1}$ (Table 7). The interaction effect of irrigation and cultivars and the interaction effect of salinity and cultivars and the combined effect of irrigation, salinity, and cultivars on seed yield in 2015 and
2016 were significant at probability level of 5\% (Table $4)$. The seed yield in interaction effect of irrigation and cultivars in treatment of $80 \%$ water requirements and Guil cultivar in 2015 and 2016 were 1,483 and $1,347 \mathrm{~kg} \mathrm{ha}^{-1}$, respectively (Table 8 ). On the interaction effect of salinity and cultivars in 2015, Jonobi cultivar with salinity of 1 $\mathrm{dS} \mathrm{m}{ }^{-1}$ showed a yield of $1,254 \mathrm{~kg} \mathrm{ha}^{-1}$, and Guil cultivar yield in 2016 with salinity of $5 \mathrm{dS} \mathrm{m}^{-1}$ was $1,127 \mathrm{~kg} \mathrm{ha}^{-1}$ (Table 9). Seed yield in combined effect of irrigation, salinity, and cultivars in the Guil cultivar and in treatment of $100 \%$ water requirement and salinity of $1 \mathrm{dS} \mathrm{m}^{-1}$ in 2015 and 2016 was 1.883 and $1,710 \mathrm{~kg} \mathrm{ha}^{-1}$, respectively (Table 10). Several reports have indicated that seed germination, seedling emergence, and early survival are susceptible to salinity and peanut cultivars in no-water stress conditions, stress at the stage of growth, stress in the flowering stage, stress in the seed-filling stage, and rain-fed treatment [13]. They reported that peanut yield is significantly affected by the value of water used. Salinity affects the growth and productive stage of a plant and it decreases dry weight and yield. Salinity negatively affects the physiological process, including water relations, and gas exchange attributes a nutritional imbalance and disturbs the stability of membranes [14]. Reduced yield in salinity conditions is due to disruption in absorption of nutrients, ion imbalance, or decreased water potential in soil and osmotic stress in photosynthesis activities of a plant [15]. In a study it was reported that the supply of a water requirement during growing season increases seed yield in peanut [16]. The effects of salinity can be in the stage of pod filling and seed growth stage, so the number and weight of seeds are two important components of seed yield that are reduced due to salinity [17].

\section{0-seed Weight}

The effects of salinity, the interaction effect of irrigation and salinity, the interaction effect of irrigation, and the interaction effect of salinity and cultivars on the weight of 100 seeds were significant in 2015 and 2016 at probability 
Table 6. Reaction of $\mathrm{WR} \times \mathrm{S}$ treatments on parameters of seed yield, 100-seed weight, number of pods per shrub, seed length, and plant height.

\begin{tabular}{|c|c|c|c|c|c|c|c|c|c|c|c|}
\hline \multirow{2}{*}{\multicolumn{2}{|c|}{$\mathrm{WR} \times \mathrm{S}$}} & \multicolumn{2}{|c|}{$\begin{array}{l}\text { Seed Yield } \\
\left(\mathrm{kg} \mathrm{ha}^{-1}\right)\end{array}$} & \multicolumn{2}{|c|}{$\begin{array}{l}\text { 100-seed weight } \\
\text { (g) }\end{array}$} & \multicolumn{2}{|c|}{$\begin{array}{l}\text { Number of pods } \\
\text { per shrub }\end{array}$} & \multicolumn{2}{|c|}{$\begin{array}{l}\text { Seed length } \\
\quad(\mathrm{cm})\end{array}$} & \multicolumn{2}{|c|}{$\begin{array}{l}\text { Plant height } \\
\qquad(\mathrm{cm})\end{array}$} \\
\hline & & 2015 & 2016 & 2015 & 2016 & 2015 & 2016 & 2015 & 2016 & 2015 & 2016 \\
\hline \multirow{4}{*}{$\mathrm{WR}_{1}$} & $\mathrm{~S}_{1}$ & $1,283 \mathrm{ab}$ & $1,258 \mathrm{a}$ & $33 a$ & $32 \mathrm{a}$ & $76 \mathrm{~b}$ & $74 \mathrm{~b}$ & $2.3 \mathrm{c}$ & $2.3 \mathrm{c}$ & $67.9 \mathrm{~b}$ & $66.6 \mathrm{~b}$ \\
\hline & $\mathrm{S}_{2}$ & $1,082 \mathrm{cde}$ & $1,061 \mathrm{c}$ & 24def & $24 \mathrm{~h}$ & $77 b$ & $75 b$ & $2.8 \mathrm{a}$ & $2.7 \mathrm{a}$ & $67.2 \mathrm{~b}$ & $65.9 \mathrm{bc}$ \\
\hline & $\mathrm{S}_{3}$ & $1,027 \mathrm{def}$ & $1,007 d$ & $30 \mathrm{~b}$ & $30 \mathrm{c}$ & $64 c$ & $62 d$ & $2.3 \mathrm{c}$ & $2.3 \mathrm{c}$ & $65.5 \mathrm{bc}$ & $64.3 \mathrm{c}$ \\
\hline & $\mathrm{S}_{4}$ & 816hi & $800 \mathrm{~h}$ & $22 \mathrm{f}$ & $22 \mathrm{i}$ & $64 c$ & $63 d$ & $2.4 \mathrm{~b}$ & $2.4 \mathrm{~b}$ & $64 b c$ & $62.8 \mathrm{~d}$ \\
\hline \multirow{4}{*}{$\mathrm{WR}_{2}$} & $\mathrm{~S}_{1}$ & $1,393 \mathrm{a}$ & $1,265 \mathrm{a}$ & $28 \mathrm{bc}$ & $26 f$ & $94 \mathrm{a}$ & $86 a$ & $2.2 \mathrm{~d}$ & $2.0 \mathrm{~d}$ & $75.3 \mathrm{a}$ & $68.4 \mathrm{a}$ \\
\hline & $\mathrm{S}_{2}$ & $1,134 \mathrm{~cd}$ & $1,030 \mathrm{~d}$ & $29 b$ & $26 f$ & $75 b$ & $68 \mathrm{c}$ & $2.7 \mathrm{a}$ & $2.4 \mathrm{~b}$ & $68.7 \mathrm{~b}$ & $62.4 \mathrm{~d}$ \\
\hline & $\mathrm{S}_{3}$ & $1,204 \mathrm{bc}$ & $1,093 b$ & $30 \mathrm{~b}$ & $27 \mathrm{e}$ & $76 \mathrm{~b}$ & $69 \mathrm{c}$ & $2.1 \mathrm{e}$ & $2.0 \mathrm{~d}$ & $75.6 \mathrm{a}$ & $68.7 \mathrm{a}$ \\
\hline & $\mathrm{S}_{4}$ & $977 \mathrm{efg}$ & $887 \mathrm{f}$ & $34 \mathrm{a}$ & $31 \mathrm{~b}$ & $63 \mathrm{c}$ & $57 \mathrm{e}$ & $2.0 \mathrm{f}$ & $1.8 \mathrm{f}$ & $69.8 b$ & $63.4 \mathrm{~cd}$ \\
\hline \multirow{4}{*}{$\mathrm{WR}_{3}$} & $\mathrm{~S}_{1}$ & 950e-h & $563 \mathrm{k}$ & $26 \mathrm{~cd}$ & $20 \mathrm{j}$ & $61 \mathrm{~d}$ & $47 \mathrm{~h}$ & $1.9 \mathrm{~g}$ & $1.5 \mathrm{i}$ & $56.6 \mathrm{c}$ & $48.1 \mathrm{~g}$ \\
\hline & $\mathrm{S}_{2}$ & $882 \mathrm{gh}$ & $709 j$ & $22 \mathrm{f}$ & $24 \mathrm{~h}$ & $62 \mathrm{~cd}$ & $49 \mathrm{~g}$ & $2.2 \mathrm{~d}$ & $1.7 \mathrm{~g}$ & $56.4 \mathrm{c}$ & $48.7 \mathrm{~g}$ \\
\hline & $\mathrm{S}_{3}$ & $906 \mathrm{fgh}$ & $875 \mathrm{f}$ & $28 \mathrm{bc}$ & $29 \mathrm{~d}$ & $54 \mathrm{e}$ & $47 \mathrm{~h}$ & $1.9 \mathrm{~g}$ & $1.7 \mathrm{~g}$ & $57.1 \mathrm{c}$ & $53.7 \mathrm{e}$ \\
\hline & $\mathrm{S}_{4}$ & 816 hi & $979 \mathrm{e}$ & $22 f$ & $27 \mathrm{e}$ & $56 \mathrm{de}$ & $54 \mathrm{f}$ & $2.0 \mathrm{f}$ & $1.5 \mathrm{i}$ & $54.9 \mathrm{~cd}$ & $50.1 \mathrm{f}$ \\
\hline \multirow{4}{*}{$\mathrm{WR}_{4}$} & $\mathrm{~S}_{1}$ & $941 \mathrm{fgh}$ & $826 f g$ & $22 f$ & $25 \mathrm{~g}$ & $61 d$ & $48 \mathrm{~g}$ & $1.7 \mathrm{i}$ & $1.9 \mathrm{e}$ & $53.9 \mathrm{~cd}$ & $53.5 \mathrm{e}$ \\
\hline & $\mathrm{S}_{2}$ & $818 \mathrm{hi}$ & $823 \mathrm{gh}$ & $22 f$ & $25 \mathrm{~g}$ & $52 \mathrm{e}$ & $49 \mathrm{~g}$ & $1.8 \mathrm{~h}$ & $1.7 \mathrm{~g}$ & $49.8 \mathrm{~d}$ & $50.7 \mathrm{f}$ \\
\hline & $\mathrm{S}_{3}$ & 826hi & 751ij & $22 \mathrm{f}$ & $24 \mathrm{~h}$ & $51 \mathrm{ef}$ & $45 \mathrm{i}$ & $1.6 \mathrm{j}$ & $1.8 \mathrm{f}$ & $53.4 \mathrm{~cd}$ & $51.5 \mathrm{f}$ \\
\hline & $\mathrm{S}_{4}$ & $723 i$ & $762 \mathrm{i}$ & $25 \mathrm{de}$ & $26 \mathrm{f}$ & $46 \mathrm{f}$ & $47 \mathrm{~h}$ & $1.5 \mathrm{k}$ & $1.6 \mathrm{~h}$ & $50.4 \mathrm{~d}$ & $50.7 \mathrm{f}$ \\
\hline
\end{tabular}

level of $1 \%$. The combined effects of irrigation, salinity, and cultivars of peanut on the weight of 100 seeds was significant in 2015 and 2016 at probability level of 5\% (Table 4). The weight of 100 seeds in salinity of 1 and $5 \mathrm{dS}$ $\mathrm{m}^{-1}$ in 2015 was $27 \mathrm{~g}$ and in 2016 was $27 \mathrm{~g}$ (Table 5). The weight of 100 seeds in 2015 and 2016 in treatment of $100 \%$ water requirement and salinity level of $1 \mathrm{dS} \mathrm{m}^{-1}$ was 33 and $32 \mathrm{~g}$, respectively (Table 6). The weight of 100 seeds in treatment of $80 \%$ water requirement and Mesri cultivar in 2015 and 2016 were 33 and $30 \mathrm{~g}$, respectively (Table 8). The weight of 100 seeds in Guil cultivar in 2015 in salinity of $1 \mathrm{dS} \mathrm{m} \mathrm{m}^{-1}$ obtained $31 \mathrm{~g}$, while the weight of 100 seeds in this cultivar in 2016 in salinity of $5 \mathrm{dS} \mathrm{m}^{-1}$ was $30 \mathrm{~g}$ (Table 8). The weight of 100 seeds in 2015 and 2016 in 100\% water requirement and salinity level of $1 \mathrm{dS} \mathrm{m}^{-1}$ in the Guil cultivar obtained 42 and $39 \mathrm{~g}$, respectively (Table 10). The effect of water shortage on the weight of 100 seeds in the growth stages was different, and as the value of stress approaches reproductive growth, its negative effect will be higher. The reduction in the weight of 100 seeds due to salinity and water shortage has an unfavorable effect on the transfer of photosynthetic substances [14].

\section{Number of Pods per Shrub}

The effects of irrigation at probability level of $5 \%$ and salinity, interaction effect of irrigation and salinity, peanut cultivars, interaction effect of irrigation and cultivars, interaction effect of salinity and cultivars, and the combined effect of irrigation, salinity, and peanut cultivars on the number of pods in a plant were significant in 2015 and 2016 at 95\% probability level (Table 4). The numbers of pods in $80 \%$ water requirement in 2015 and 2016 were 77 and 70, respectively, and at salinity

Table 7. Mean comparison of peanut cultivars on seed yield, 100-seed weight, number of pods per shrub, seed length, and plant height.

\begin{tabular}{|c|c|c|c|c|c|c|c|c|c|c|}
\hline \multirow{2}{*}{ Treatments } & \multicolumn{2}{|c|}{ Seed Yield $\left(\mathrm{kg} \mathrm{ha}^{-1}\right)$} & \multicolumn{2}{|c|}{100 -seed weight $(\mathrm{g})$} & \multicolumn{2}{|c|}{ Number of pods per shrub } & \multicolumn{2}{|c|}{ Seed length $(\mathrm{cm})$} & \multicolumn{2}{|c|}{ Plant height $(\mathrm{cm})$} \\
\hline & 2015 & 2016 & 2015 & 2016 & 2015 & 2016 & 2015 & 2016 & 2015 & 2016 \\
\hline $\mathrm{V}_{1}$ & $1,008 \mathrm{a}$ & $934 \mathrm{~b}$ & $26 \mathrm{~b}$ & $26 \mathrm{~b}$ & $66 a$ & $67 \mathrm{a}$ & $2.1 \mathrm{a}$ & $1.9 \mathrm{~d}$ & $61.5 b$ & $57.8 \mathrm{c}$ \\
\hline $\mathrm{V}_{2}$ & $966 \mathrm{~b}$ & $858 \mathrm{~d}$ & $26 \mathrm{~b}$ & $25 \mathrm{c}$ & $62 \mathrm{c}$ & $63 \mathrm{~d}$ & $2.1 \mathrm{a}$ & $1.7 \mathrm{c}$ & $62.5 \mathrm{a}$ & $58.7 \mathrm{~b}$ \\
\hline $\mathrm{V}_{3}$ & $1,033 b$ & $970 \mathrm{a}$ & $27 \mathrm{a}$ & $28 \mathrm{a}$ & $63 b$ & $64 c$ & $2 b$ & $2 \mathrm{a}$ & $61.7 \mathrm{~b}$ & $57 \mathrm{~d}$ \\
\hline $\mathrm{V}_{4}$ & $937 \mathrm{c}$ & $911 \mathrm{c}$ & $26 b$ & $25 \mathrm{~d}$ & $67 a$ & $68 \mathrm{a}$ & $2 b$ & $1.8 \mathrm{~b}$ & $61 b$ & $58.8 \mathrm{a}$ \\
\hline
\end{tabular}


Table 8. Reaction of $\mathrm{WR} \times \mathrm{V}$ treatments on parameters of seed yield, 100-seed weight, number of pods per shrub, seed length, and plant height.

\begin{tabular}{|c|c|c|c|c|c|c|c|c|c|c|c|}
\hline \multicolumn{2}{|c|}{$\mathrm{WR} \times \mathrm{V}$} & \multicolumn{2}{|c|}{$\begin{array}{l}\text { Seed Yield } \\
\left(\mathrm{kg} \mathrm{ha}^{-1}\right)\end{array}$} & \multicolumn{2}{|c|}{$\begin{array}{l}\text { 100-seed weight } \\
\text { (g) }\end{array}$} & \multicolumn{2}{|c|}{$\begin{array}{l}\text { Number of pods per } \\
\text { shrub }\end{array}$} & \multicolumn{2}{|c|}{$\begin{array}{l}\text { Seed length } \\
\quad(\mathrm{cm})\end{array}$} & \multicolumn{2}{|c|}{$\begin{array}{l}\text { Plant height } \\
\qquad(\mathrm{cm})\end{array}$} \\
\hline & & 2015 & 2016 & 2015 & 2016 & 2015 & 2016 & 2015 & 2016 & 2015 & 2016 \\
\hline \multirow{4}{*}{$\mathrm{WR}_{1}$} & $\mathrm{~V}_{1}$ & $820 \mathrm{ef}$ & $805 i$ & $27 \mathrm{de}$ & $26 \mathrm{e}$ & $57 \mathrm{e}$ & $56 \mathrm{~h}$ & $2.5 \mathrm{a}$ & $2.4 \mathrm{a}$ & $64.8 \mathrm{f}$ & $63.6 \mathrm{~g}$ \\
\hline & $\mathrm{V}_{2}$ & $1,035 \mathrm{~d}$ & $1,015 \mathrm{e}$ & $28 \mathrm{bcd}$ & $28 \mathrm{~d}$ & $67 d$ & $66 \mathrm{e}$ & $2.5 \mathrm{a}$ & $2.4 \mathrm{a}$ & $66.6 \mathrm{e}$ & $65.3 \mathrm{e}$ \\
\hline & $\mathrm{V}_{3}$ & $1,278 \mathrm{~b}$ & $1,253 b$ & $30 \mathrm{~b}$ & $29 b$ & $75 \mathrm{c}$ & $74 \mathrm{c}$ & $2.5 \mathrm{a}$ & $2.4 \mathrm{a}$ & $67 d$ & $65.7 \mathrm{~d}$ \\
\hline & $\mathrm{V}_{4}$ & $1,074 \mathrm{~cd}$ & $1,053 \mathrm{~d}$ & $25 \mathrm{ef}$ & $24 \mathrm{i}$ & $81 \mathrm{~b}$ & $80 \mathrm{~b}$ & $2.4 \mathrm{~b}$ & $2.4 \mathrm{a}$ & $66.2 \mathrm{e}$ & $65 f$ \\
\hline \multirow{4}{*}{$\mathrm{WR}_{2}$} & $\mathrm{~V}_{1}$ & $1,483 a$ & $1,347 \mathrm{a}$ & $29 \mathrm{bcd}$ & $26 \mathrm{e}$ & $94 a$ & $86 a$ & $2.2 \mathrm{c}$ & $2 d$ & $73.5 \mathrm{ab}$ & $66.8 \mathrm{~b}$ \\
\hline & $\mathrm{V}_{2}$ & $1,197 \mathrm{bc}$ & $1,088 \mathrm{c}$ & $30 \mathrm{bc}$ & $27 d$ & $76 \mathrm{bc}$ & $69 d$ & $2.3 b c$ & $2.1 \mathrm{c}$ & $74 a$ & $67.2 \mathrm{a}$ \\
\hline & $\mathrm{V}_{3}$ & $1,033 \mathrm{~d}$ & $939 \mathrm{f}$ & $28 \mathrm{bcd}$ & $26 f g$ & $70 \mathrm{~cd}$ & $64 f$ & $2.3 \mathrm{bc}$ & $2.1 \mathrm{c}$ & $72.8 \mathrm{cb}$ & $66.1 \mathrm{c}$ \\
\hline & $\mathrm{V}_{4}$ & $993 d$ & $902 \mathrm{~g}$ & $33 a$ & $30 \mathrm{a}$ & $68 \mathrm{~d}$ & $62 \mathrm{~g}$ & $2.2 \mathrm{c}$ & $2 d$ & $69.2 \mathrm{c}$ & $62.8 \mathrm{~h}$ \\
\hline \multirow{4}{*}{$\mathrm{WR}_{3}$} & $\mathrm{~V}_{1}$ & $751 \mathrm{f}$ & $781 \mathrm{i}$ & $25 \mathrm{ef}$ & $26 f g$ & $51 \mathrm{fg}$ & $51 \mathrm{i}$ & $2 d$ & $1.5 \mathrm{i}$ & $55.2 \mathrm{~h}$ & $49.5 n$ \\
\hline & $\mathrm{V}_{2}$ & $822 \mathrm{ef}$ & $616 \mathrm{k}$ & $24 f$ & $22 \mathrm{j}$ & $55 \mathrm{ef}$ & $46 \mathrm{k}$ & $2 d$ & $1.6 \mathrm{~h}$ & $56.5 \mathrm{~g}$ & $50 \mathrm{~m}$ \\
\hline & $\mathrm{V}_{3}$ & $1,039 d$ & $833 \mathrm{~h}$ & $27 \mathrm{cde}$ & $27 \mathrm{~d}$ & $59 \mathrm{e}$ & 451 & $2 d$ & $1.7 \mathrm{~g}$ & $56.1 \mathrm{gh}$ & $48.4 \mathrm{o}$ \\
\hline & $\mathrm{V}_{4}$ & $941 \mathrm{de}$ & $897 \mathrm{~g}$ & $23 f$ & $25 \mathrm{~h}$ & $67 d$ & $56 \mathrm{~h}$ & $2 d$ & $1.6 \mathrm{~h}$ & $57.1 \mathrm{~g}$ & $52.7 \mathrm{j}$ \\
\hline \multirow{4}{*}{$\mathrm{WR}_{4}$} & $\mathrm{~V}_{1}$ & $977 d$ & $804 \mathrm{i}$ & $23 f$ & $26 \mathrm{ef}$ & $61 \mathrm{e}$ & $47 \mathrm{j}$ & $1.6 \mathrm{f}$ & $1.6 \mathrm{~h}$ & $52.4 \mathrm{i}$ & 51.61 \\
\hline & $\mathrm{V}_{2}$ & $810 \mathrm{ef}$ & $713 \mathrm{j}$ & $23 f$ & $26 \mathrm{~g}$ & $51 \mathrm{fg}$ & 441 & $1.7 \mathrm{e}$ & $1.6 \mathrm{~h}$ & $52.9 \mathrm{i}$ & $52.2 \mathrm{k}$ \\
\hline & $\mathrm{V}_{3}$ & $781 \mathrm{f}$ & $855 \mathrm{~h}$ & $23 f$ & $28 \mathrm{c}$ & $49 \mathrm{~g}$ & $47 \mathrm{jk}$ & $1.7 \mathrm{e}$ & $1.9 \mathrm{e}$ & $50.8 \mathrm{j}$ & $48 p$ \\
\hline & $\mathrm{V}_{4}$ & $740 f$ & $790 \mathrm{i}$ & $23 f$ & $21 \mathrm{k}$ & $50 \mathrm{fg}$ & $52 \mathrm{i}$ & $1.6 \mathrm{f}$ & $1.8 \mathrm{f}$ & $51.4 \mathrm{ij}$ & $54.7 \mathrm{i}$ \\
\hline
\end{tabular}

Table 9. Reaction of $\mathrm{S} \times \mathrm{V}$ treatments on parameters of seed yield, 100-seed weight, number of pods per shrub, seed length, and plant height.

\begin{tabular}{|c|c|c|c|c|c|c|c|c|c|c|c|}
\hline \multicolumn{2}{|c|}{$\mathrm{S} \times \mathrm{V}$} & \multicolumn{2}{|c|}{$\begin{array}{l}\text { Seed Yield } \\
\left(\mathrm{kg} \mathrm{ha}^{-1}\right)\end{array}$} & \multicolumn{2}{|c|}{$\begin{array}{l}\text { 100-seed weight } \\
(\mathrm{g})\end{array}$} & \multicolumn{2}{|c|}{$\begin{array}{l}\text { Number of pods per } \\
\text { shrub }\end{array}$} & \multicolumn{2}{|c|}{$\begin{array}{l}\text { Seed length } \\
\quad(\mathrm{cm})\end{array}$} & \multicolumn{2}{|c|}{$\begin{array}{l}\text { Plant height } \\
\text { (cm) }\end{array}$} \\
\hline & & 2015 & 2016 & 2015 & 2016 & 2015 & 2016 & 2015 & 2016 & 2015 & 2016 \\
\hline \multirow{4}{*}{$\mathrm{S}_{1}$} & $\mathrm{~V}_{1}$ & $1,042 \mathrm{~cd}$ & $1,079 \mathrm{~b}$ & $31 \mathrm{a}$ & $30 \mathrm{a}$ & $71 b$ & $69 a$ & $2.2 \mathrm{~d}$ & $2 d$ & $59.9 \mathrm{e}$ & $57.6 \mathrm{bc}$ \\
\hline & $\mathrm{V}_{2}$ & $1,222 \mathrm{ab}$ & $1,007 \mathrm{c}$ & $28 b c$ & $26 \mathrm{e}$ & $75 \mathrm{ab}$ & $64 b$ & $2.1 \mathrm{e}$ & $2 d$ & $64 b$ & $59.5 b$ \\
\hline & $\mathrm{V}_{3}$ & $1,254 \mathrm{a}$ & $1,088 \mathrm{~b}$ & $30 \mathrm{ab}$ & $29 b$ & $74 b$ & $64 b$ & $2.1 \mathrm{e}$ & $2.1 \mathrm{c}$ & $63.6 \mathrm{~b}$ & $59 b$ \\
\hline & $\mathrm{V}_{4}$ & $1,087 \mathrm{bcd}$ & $868 f$ & $24 \mathrm{ef}$ & $22 \mathrm{i}$ & $77 \mathrm{a}$ & $64 b$ & $1.9 \mathrm{~g}$ & $1.7 \mathrm{~h}$ & $62.6 \mathrm{bc}$ & $59.3 b$ \\
\hline \multirow{4}{*}{$\mathrm{S}_{2}$} & $\mathrm{~V}_{1}$ & $965 \mathrm{def}$ & $840 \mathrm{~g}$ & $24 \mathrm{ef}$ & $24 \mathrm{~g}$ & $69 \mathrm{c}$ & $60 d$ & $2.3 \mathrm{c}$ & $2.1 \mathrm{c}$ & $63.8 \mathrm{~b}$ & $59.4 b$ \\
\hline & $\mathrm{V}_{2}$ & 1,119abc & $872 \mathrm{f}$ & $24 \mathrm{ef}$ & $22 \mathrm{i}$ & $75 \mathrm{ab}$ & $64 d$ & $2.3 \mathrm{c}$ & $2 d$ & $66.5 \mathrm{a}$ & $62.1 \mathrm{a}$ \\
\hline & $\mathrm{V}_{3}$ & $1,048 \mathrm{~cd}$ & $981 d$ & $25 \mathrm{de}$ & $28 \mathrm{c}$ & $63 \mathrm{ef}$ & $57 \mathrm{e}$ & $2.5 \mathrm{a}$ & $2.2 \mathrm{~b}$ & $60.8 \mathrm{~d}$ & $55.8 b$ \\
\hline & $\mathrm{V}_{4}$ & 783ghi & $930 \mathrm{e}$ & $25 \mathrm{de}$ & $26 \mathrm{e}$ & $58 \mathrm{~g}$ & $61 \mathrm{~cd}$ & $2.4 \mathrm{~b}$ & $2.3 \mathrm{a}$ & $57.5 f$ & $56 \mathrm{c}$ \\
\hline \multirow{4}{*}{$\mathrm{S}_{3}$} & $\mathrm{~V}_{1}$ & 1,189ab & $1,127 \mathrm{a}$ & $28 b c$ & $29 b$ & $68 \mathrm{~cd}$ & $62 c$ & $2.2 \mathrm{~d}$ & $1.9 \mathrm{f}$ & $59.3 \mathrm{e}$ & $57.6 \mathrm{bc}$ \\
\hline & $\mathrm{V}_{2}$ & $835 \mathrm{fgh}$ & $890 \mathrm{f}$ & $27 \mathrm{~cd}$ & $28 \mathrm{c}$ & $50 \mathrm{i}$ & $52 \mathrm{~h}$ & $2.2 \mathrm{~d}$ & $2 d$ & $59.9 \mathrm{e}$ & $56.6 \mathrm{c}$ \\
\hline & $\mathrm{V}_{3}$ & $1,103 \mathrm{bcd}$ & $944 \mathrm{e}$ & $30 \mathrm{ab}$ & $29 \mathrm{~b}$ & $64 \mathrm{e}$ & $55 f$ & $1.9 \mathrm{~g}$ & $2 d$ & $61.8 \mathrm{c}$ & $56.2 \mathrm{c}$ \\
\hline & $\mathrm{V}_{4}$ & $836 f g h$ & $766 \mathrm{~h}$ & $24 \mathrm{ef}$ & $23 \mathrm{~h}$ & $62 f$ & $54 \mathrm{fg}$ & $1.7 \mathrm{i}$ & $1.8 \mathrm{~g}$ & $63.9 \mathrm{~b}$ & $62.3 \mathrm{a}$ \\
\hline \multirow{4}{*}{$\mathrm{S}_{4}$} & $\mathrm{~V}_{1}$ & $873 \mathrm{efg}$ & $821 \mathrm{~g}$ & $25 \mathrm{de}$ & $25 f$ & $59 \mathrm{~g}$ & $55 f$ & $1.8 \mathrm{~h}$ & $1.7 \mathrm{~h}$ & $59.2 \mathrm{e}$ & $55.6 \mathrm{c}$ \\
\hline & $\mathrm{V}_{2}$ & $689 \mathrm{i}$ & $662 \mathrm{i}$ & $25 \mathrm{de}$ & $26 \mathrm{e}$ & $47 j$ & $44 \mathrm{i}$ & $1.9 \mathrm{~g}$ & $1.8 \mathrm{~g}$ & $59.6 \mathrm{e}$ & $56.6 \mathrm{c}$ \\
\hline & $\mathrm{V}_{3}$ & 727hi & $867 f$ & $22 \mathrm{f}$ & $26 \mathrm{e}$ & $53 \mathrm{~h}$ & $53 \mathrm{gh}$ & $2 d$ & $1.9 \mathrm{f}$ & $60.5 \mathrm{~d}$ & $57.2 \mathrm{bc}$ \\
\hline & $\mathrm{V}_{4}$ & $1,005 \mathrm{cde}$ & $950 \mathrm{e}$ & $27 \mathrm{~cd}$ & $27 d$ & $67 d$ & $63 \mathrm{bc}$ & $2 d$ & $2 d$ & $63.6 \mathrm{~b}$ & $58.8 \mathrm{c}$ \\
\hline
\end{tabular}


Table 10. Reaction of $\mathrm{WR} \times \mathrm{S} \times \mathrm{V}$ treatments on parameters of seed yield, 100-seed weight, number of pods per shrub, seed length, and plant height.

\begin{tabular}{|c|c|c|c|c|c|c|c|c|c|c|c|c|}
\hline \multicolumn{3}{|c|}{$\mathrm{WR} \times \mathrm{S} \times \mathrm{V}$} & \multicolumn{2}{|c|}{$\begin{array}{l}\text { Seed Yield } \\
\left(\mathrm{kg} \mathrm{ha}^{-1}\right)\end{array}$} & \multicolumn{2}{|c|}{$\begin{array}{l}\text { 100-seed weight } \\
(\mathrm{g})\end{array}$} & \multicolumn{2}{|c|}{$\begin{array}{l}\text { Number of pods } \\
\text { per shrub }\end{array}$} & \multicolumn{2}{|c|}{$\begin{array}{l}\text { Seed length } \\
\quad(\mathrm{cm})\end{array}$} & \multicolumn{2}{|c|}{$\begin{array}{l}\text { Plant height } \\
\text { (cm) }\end{array}$} \\
\hline & & & & & & & & & & & & \\
\hline \multirow{16}{*}{$\mathrm{WR}_{1}$} & \multirow{4}{*}{$\mathrm{S}_{1}$} & $\mathrm{~V}_{1}$ & $1,883 \mathrm{a}$ & $1,710 \mathrm{a}$ & $32 \mathrm{~d}-\mathrm{g}$ & $32 \mathrm{e}$ & $107 \mathrm{a}$ & $97 \mathrm{a}$ & $2.2 \mathrm{e}-\mathrm{h}$ & $2.2 \mathrm{f}$ & $71.0 \mathrm{f}$ & $69.6 \mathrm{c}$ \\
\hline & & $\mathrm{V}_{2}$ & $1,356 \mathrm{~b}-\mathrm{f}$ & $1,331 \mathrm{e}$ & $36 \mathrm{bcd}$ & $35 \mathrm{c}$ & $78 \mathrm{ef}$ & $77 \mathrm{f}$ & $2.6 \mathrm{bcd}$ & $2.5 \mathrm{c}$ & $67.0 \mathrm{ij}$ & $65.7 \mathrm{~g}$ \\
\hline & & $\mathrm{V}_{3}$ & $1,599 b$ & $1,568 \mathrm{~b}$ & $38 \mathrm{abc}$ & $37 \mathrm{~b}$ & $84 \mathrm{de}$ & $82 \mathrm{e}$ & $2.4 \mathrm{~d}-\mathrm{g}$ & $2.3 \mathrm{e}$ & $66.3 \mathrm{jk}$ & $65.0 \mathrm{~g}$ \\
\hline & & $\mathrm{V}_{4}$ & 984i-r & 893pqr & $42 \mathrm{a}$ & $39 a$ & $73 \mathrm{fgh}$ & $66 \mathrm{~h}$ & $2.1 \mathrm{~h}-1$ & $2.1 \mathrm{~g}$ & $67.5 \mathrm{ij}$ & $66.2 \mathrm{f}$ \\
\hline & \multirow{4}{*}{$\mathrm{S}_{2}$} & $\mathrm{~V}_{1}$ & $857 \mathrm{n}-\mathrm{w}$ & $841 \mathrm{rst}$ & $24 \mathrm{o}-\mathrm{u}$ & 23 op & 66h-n & $65 \mathrm{~h}$ & $2.8 \mathrm{ab}$ & $2.8 \mathrm{a}$ & $70.3 \mathrm{fg}$ & $69.0 \mathrm{c}$ \\
\hline & & $\mathrm{V}_{2}$ & $1,195 \mathrm{~b}$ & 1,172ghi & $25 \mathrm{~m}-\mathrm{t}$ & $24 \mathrm{mno}$ & $85 \mathrm{de}$ & $83 \mathrm{e}$ & $2.7 \mathrm{bc}$ & $2.6 \mathrm{~b}$ & $63.11 \mathrm{~m}$ & $61.9 \mathrm{k}$ \\
\hline & & $\mathrm{V}_{3}$ & $1,463 \mathrm{bcd}$ &, $1435 \mathrm{c}$ & $261-\mathrm{s}$ & $251 \mathrm{~m}$ & $85 \mathrm{de}$ & $83 \mathrm{e}$ & $2.8 \mathrm{ab}$ & $2.8 \mathrm{a}$ & $69.0 \mathrm{gh}$ & $67.7 \mathrm{e}$ \\
\hline & & $\mathrm{V}_{4}$ & $8130-x$ & $797 \mathrm{tu}$ & $22 \mathrm{~s}-\mathrm{w}$ & $22 \mathrm{p}$ & $72 \mathrm{fgh}$ & $71 \mathrm{~g}$ & $2.8 \mathrm{ab}$ & $2.8 \mathrm{a}$ & $66.4 \mathrm{jk}$ & $65.1 \mathrm{~g}$ \\
\hline & \multirow{4}{*}{$\mathrm{S}_{3}$} & $\mathrm{~V}_{1}$ & $8170-x$ & $802 \mathrm{t}$ & $28 \mathrm{~h}-\mathrm{o}$ & $28 \mathrm{ij}$ & $52 p-y$ & $51 \mathrm{mno}$ & $2.6 \mathrm{bcd}$ & $2.5 \mathrm{c}$ & $58.2 \mathrm{op}$ & $57.1 \mathrm{n}$ \\
\hline & & $\mathrm{V}_{2}$ & $1,002 \mathrm{~h}-\mathrm{r}$ & $9,821 \mathrm{mn}$ & $31 \mathrm{~d}-\mathrm{h}$ & $31 \mathrm{ef}$ & $56 \mathrm{n}-\mathrm{u}$ & $55 \mathrm{jk}$ & $2.2 \mathrm{e}-\mathrm{h}$ & $2.2 \mathrm{f}$ & $69.9 \mathrm{gh}$ & $68.5 \mathrm{~d}$ \\
\hline & & $\mathrm{V}_{3}$ & $1,374 b-f$ & $1,348 \mathrm{de}$ & $39 \mathrm{ab}$ & $37 \mathrm{~b}$ & $71 \mathrm{f}-\mathrm{i}$ & $69 \mathrm{~g}$ & $2.2 \mathrm{e}-\mathrm{h}$ & $2.2 \mathrm{f}$ & $68.9 \mathrm{hi}$ & $67.5 \mathrm{e}$ \\
\hline & & $\mathrm{V}_{4}$ & 914l-v & 896opq & $22 \mathrm{~s}-\mathrm{w}$ & $22 p$ & $77 \mathrm{efg}$ & $76 f$ & $2.1 \mathrm{~h}-1$ & $2.1 \mathrm{~g}$ & $65.2 \mathrm{kl}$ & $63.9 \mathrm{i}$ \\
\hline & \multirow{4}{*}{$\mathrm{S}_{4}$} & $\mathrm{~V}_{1}$ & $764 p-x$ & 749uv & $24 \mathrm{o}-\mathrm{u}$ & 23 op & $62 \mathrm{i}-\mathrm{o}$ & $60 \mathrm{i}$ & $2.2 \mathrm{e}-\mathrm{h}$ & $2.2 \mathrm{f}$ & 59.7 no & $58.5 \mathrm{~m}$ \\
\hline & & $\mathrm{V}_{2}$ & 588wx & $577 \mathrm{yz}$ & $20 \mathrm{vwx}$ & $20 \mathrm{qr}$ & $51 \mathrm{q}-\mathrm{y}$ & $50 \mathrm{~m}-\mathrm{p}$ & $2.5 \mathrm{cde}$ & $2.4 \mathrm{~d}$ & $66.5 \mathrm{jk}$ & $65.2 \mathrm{~g}$ \\
\hline & & $\mathrm{V}_{3}$ & $675 t-x$ & $662 \mathrm{yz}$ & $17 x$ & $17 \mathrm{t}$ & $62 \mathrm{i}-\mathrm{o}$ & $60 \mathrm{i}$ & $2.5 \mathrm{cde}$ & $2.4 \mathrm{~d}$ & $63.91 \mathrm{~m}$ & $62.7 \mathrm{j}$ \\
\hline & & $\mathrm{V}_{4}$ & $1,235 \mathrm{~d}-\mathrm{i}$ & $1,212 \mathrm{~g}$ & $28 \mathrm{~h}-\mathrm{o}$ & $28 \mathrm{ij}$ & $84 \mathrm{de}$ & $82 \mathrm{e}$ & $2.6 \mathrm{bcd}$ & $2.5 \mathrm{c}$ & $65.8 \mathrm{kl}$ & $64.6 \mathrm{~h}$ \\
\hline \multirow{16}{*}{$\mathrm{WR}_{2}$} & \multirow{4}{*}{$\mathrm{S}_{1}$} & $\mathrm{~V}_{1}$ & $1,432 b-e$ & $1,300 \mathrm{ef}$ & $25 \mathrm{~m}-\mathrm{t}$ & 23 op & $104 \mathrm{ab}$ & $94 \mathrm{~b}$ & $2.3 \mathrm{efg}$ & $2.1 \mathrm{~g}$ & $73.0 \mathrm{~d}$ & $66.3 \mathrm{f}$ \\
\hline & & $\mathrm{V}_{2}$ & $1,554 \mathrm{bc}$ & $1,411 \mathrm{c}$ & $28 \mathrm{~h}-\mathrm{o}$ & $251 \mathrm{~m}$ & $99 \mathrm{abc}$ & $91 \mathrm{c}$ & $2.1 \mathrm{~h}-1$ & $1.9 \mathrm{i}$ & $77.8 \mathrm{~b}$ & $70.6 b$ \\
\hline & & $\mathrm{V}_{3}$ & $1,308 \mathrm{c}-\mathrm{g}$ & $1,188 \mathrm{gh}$ & $29 \mathrm{f}-\mathrm{k}$ & $26 \mathrm{kl}$ & $91 \mathrm{~cd}$ & $82 \mathrm{e}$ & $2.3 \mathrm{efg}$ & $2.1 \mathrm{~g}$ & $77.8 \mathrm{~b}$ & $70.6 b$ \\
\hline & & $\mathrm{V}_{4}$ & $1,279 \mathrm{c}-\mathrm{h}$ & 1,161ghi & $30 e-i$ & $28 \mathrm{ij}$ & $85 \mathrm{de}$ & $78 \mathrm{f}$ & $2.1 \mathrm{~h}-1$ & $1.9 \mathrm{i}$ & $72.8 \mathrm{e}$ & $66.1 \mathrm{f}$ \\
\hline & \multirow{4}{*}{$\mathrm{S}_{2}$} & $\mathrm{~V}_{1}$ & 1,405b-e & $1276 \mathrm{f}$ & $28 \mathrm{~h}-\mathrm{o}$ & $251 \mathrm{~m}$ & $96 \mathrm{c}$ & $87 d$ & $2.4 \mathrm{~d}-\mathrm{g}$ & $2.2 \mathrm{f}$ & $73.8 \mathrm{~d}$ & $67.0 \mathrm{e}$ \\
\hline & & $\mathrm{V}_{2}$ & $1,535 b c$ & $1,394 \mathrm{~cd}$ & $31 \mathrm{~d}-\mathrm{h}$ & $29 \mathrm{hi}$ & $97 \mathrm{bc}$ & $88 \mathrm{~d}$ & $2.7 \mathrm{bc}$ & $2.4 \mathrm{~d}$ & $71.5 \mathrm{a}$ & $64.9 \mathrm{a}$ \\
\hline & & $\mathrm{V}_{3}$ & $872 n-v$ & $792 \mathrm{tu}$ & $27 i-p$ & $24 \mathrm{mno}$ & $59 \mathrm{k}-\mathrm{r}$ & $54 \mathrm{kl}$ & $3.0 \mathrm{a}$ & $2.8 \mathrm{a}$ & $69.3 \mathrm{gh}$ & $62.9 \mathrm{j}$ \\
\hline & & $\mathrm{V}_{4}$ & $724 r-x$ & $657 x y$ & $30 e-i$ & $28 \mathrm{ij}$ & $50 \mathrm{r}-\mathrm{y}$ & $46 r$ & $2.7 \mathrm{bc}$ & $2.4 \mathrm{~d}$ & $60.3 \mathrm{mn}$ & $54.8 \mathrm{p}$ \\
\hline & \multirow{4}{*}{$\mathrm{S}_{3}$} & $\mathrm{~V}_{1}$ & $843 n-w$ & $827 \mathrm{st}$ & $33 d-f$ & $32 \mathrm{e}$ & 50r-y & $49 n-q$ & $2.5 \mathrm{cde}$ & $2.3 \mathrm{e}$ & $73.51 \mathrm{~m}$ & $66.8 \mathrm{f}$ \\
\hline & & $\mathrm{V}_{2}$ & $744 r-x$ & $675 x y$ & $25 \mathrm{~m}-\mathrm{t}$ & 23 op & $530-x$ & $47 \mathrm{qr}$ & $2.7 \mathrm{bc}$ & $2.4 \mathrm{~d}$ & $80.3 \mathrm{f}$ & $72.9 \mathrm{~h}$ \\
\hline & & $\mathrm{V}_{3}$ & $1,202 \mathrm{~d}-\mathrm{k}$ & $1,091 \mathrm{jk}$ & $30 e-i$ & $28 \mathrm{ij}$ & $79 \mathrm{ef}$ & $71 \mathrm{~g}$ & $1.8 \mathrm{o}-\mathrm{t}$ & $1.7 \mathrm{k}$ & $72.3 \mathrm{e}$ & $65.7 \mathrm{~g}$ \\
\hline & & $\mathrm{V}_{4}$ & $987 \mathrm{i}-\mathrm{r}$ & 897opq & $30 e-i$ & $28 \mathrm{ij}$ & $67 \mathrm{~h}-1$ & $61 \mathrm{i}$ & 1.6tuv & $1.4 \mathrm{n}$ & $76.3 \mathrm{c}$ & $69.3 \mathrm{c}$ \\
\hline & \multirow{4}{*}{$\mathrm{S}_{4}$} & $\mathrm{~V}_{1}$ & $1,214 \mathrm{~d}-\mathrm{k}$ & $1,102 \mathrm{jk}$ & $30 e-i$ & $28 \mathrm{ij}$ & $73 \mathrm{fgh}$ & $66 \mathrm{~h}$ & $1.7 q-u$ & $1.5 \mathrm{~m}$ & $73.8 \mathrm{~d}$ & $67.0 \mathrm{e}$ \\
\hline & & $\mathrm{V}_{2}$ & $958 \mathrm{i}-\mathrm{s}$ & $870 \mathrm{qrs}$ & $34 \mathrm{cde}$ & $31 \mathrm{ef}$ & $54 \mathrm{o}-\mathrm{w}$ & $49 n-q$ & $1.8 \mathrm{o}-\mathrm{t}$ & $1.7 \mathrm{k}$ & $66.6 \mathrm{jk}$ & 60.51 \\
\hline & & $\mathrm{V}_{3}$ & $752 \mathrm{r}-\mathrm{x}$ & 683wxy & $28 \mathrm{~h}-\mathrm{o}$ & $251 \mathrm{~m}$ & $530-x$ & $48 \mathrm{qr}$ & $2.1 \mathrm{~h}-1$ & $1.9 \mathrm{i}$ & $71.7 \mathrm{f}$ & $65.1 \mathrm{~g}$ \\
\hline & & $\mathrm{V}_{4}$ & $1,333 b-f$ & $1307 \mathrm{ef}$ & $261-s$ & $251 \mathrm{~m}$ & $92 \mathrm{~cd}$ & $90 \mathrm{c}$ & $2.4 \mathrm{~d}-\mathrm{g}$ & $2.2 \mathrm{f}$ & $67.2 \mathrm{ij}$ & $61.1 \mathrm{k}$ \\
\hline \multirow{4}{*}{$\mathrm{WR}_{3}$} & \multirow{4}{*}{$\mathrm{S}_{1}$} & $\mathrm{~V}_{1}$ & $699 \mathrm{~s}-\mathrm{x}$ & $588 \mathrm{yz}$ & $28 \mathrm{~h}-\mathrm{o}$ & $24 \mathrm{mno}$ & $47 \mathrm{t}-\mathrm{y}$ & $49 n-q$ & $1.9 \mathrm{~m}-\mathrm{r}$ & 1.61 & $58.1 \mathrm{op}$ & $47.2 \mathrm{w}$ \\
\hline & & $\mathrm{V}_{2}$ & $940 \mathrm{j}-\mathrm{s}$ & $405 z$ & $28 \mathrm{~h}-\mathrm{o}$ & $19 \mathrm{rs}$ & $59 \mathrm{k}-\mathrm{r}$ & $39 t$ & $2.0 \mathrm{k}-\mathrm{p}$ & $1.3 \mathrm{o}$ & $56.9 \mathrm{qr}$ & $50.6 \mathrm{t}$ \\
\hline & & $\mathrm{V}_{3}$ & $1,217 \mathrm{~d}-\mathrm{j}$ & $796 \mathrm{tu}$ & $29 \mathrm{f}-\mathrm{k}$ & $20 \mathrm{qr}$ & 66h-n & $47 \mathrm{qr}$ & $2.0 \mathrm{k}-\mathrm{p}$ & 1.61 & $56.7 \mathrm{qr}$ & $51.2 \mathrm{~s}$ \\
\hline & & $\mathrm{V}_{4}$ & $946 \mathrm{j}-\mathrm{t}$ & $464 z$ & $21 \mathrm{u}-\mathrm{x}$ & $16 \mathrm{t}$ & $72 \mathrm{fgh}$ & $521 \mathrm{~m}$ & $1.7 \mathrm{q}-\mathrm{u}$ & $1.4 \mathrm{n}$ & $54.7 \mathrm{~s}$ & $43.2 \mathrm{y}$ \\
\hline
\end{tabular}


Table 10. Continued.

\begin{tabular}{|c|c|c|c|c|c|c|c|c|c|c|c|c|}
\hline \multirow{12}{*}{$\mathrm{WR}_{3}$} & \multirow{4}{*}{$\mathrm{S}_{2}$} & $\mathrm{~V}_{1}$ & $680 s-x$ & $508 \mathrm{yz}$ & $21 u-x$ & $20 \mathrm{qr}$ & $55 n-v$ & $47 \mathrm{qr}$ & $2.2 \mathrm{e}-\mathrm{h}$ & $1.5 \mathrm{~m}$ & 58.1op & $48.4 \mathrm{v}$ \\
\hline & & $\mathrm{V}_{2}$ & $855 n-w$ & $437 z$ & $21 u-x$ & $18 \mathrm{~s}$ & $64 \mathrm{~h}-\mathrm{n}$ & $43 \mathrm{~s}$ & $2.2 \mathrm{e}-\mathrm{h}$ & $1.7 \mathrm{k}$ & $52.6 u$ & $44.6 x$ \\
\hline & & $\mathrm{V}_{3}$ & $1,120 \mathrm{f}-\mathrm{n}$ & $749 \mathrm{uv}$ & $25 \mathrm{~m}-\mathrm{t}$ & $30 \mathrm{fgh}$ & $64 \mathrm{~h}-\mathrm{n}$ & $43 \mathrm{~s}$ & $2.2 \mathrm{e}-\mathrm{h}$ & 1.61 & $57.1 \mathrm{pq}$ & $47.8 \mathrm{w}$ \\
\hline & & $\mathrm{V}_{4}$ & $870 n-v$ & 1,142hij & $22 \mathrm{~s}-\mathrm{w}$ & $27 \mathrm{jk}$ & $64 \mathrm{~h}-\mathrm{n}$ & $65 \mathrm{~h}$ & $2.4 \mathrm{~d}-\mathrm{g}$ & $2.1 \mathrm{~g}$ & $57.7 \mathrm{pq}$ & $54.0 \mathrm{p}$ \\
\hline & \multirow{4}{*}{$\mathrm{S}_{3}$} & $\mathrm{~V}_{1}$ & $870 n-v$ & $1,134 \mathrm{ijk}$ & $29 \mathrm{f}-\mathrm{k}$ & $36 \mathrm{c}$ & $48 s-y$ & $51 \mathrm{mn}$ & $2.0 \mathrm{k}-\mathrm{p}$ & $1.4 \mathrm{n}$ & $53.0 \mathrm{t}$ & $54.4 p$ \\
\hline & & $\mathrm{V}_{2}$ & $935 \mathrm{k}-\mathrm{u}$ & 10061 & $29 \mathrm{f}-\mathrm{k}$ & $30 \mathrm{fgh}$ & $52 p-y$ & $56 \mathrm{j}$ & $1.9 \mathrm{~m}-\mathrm{r}$ & 1.61 & $60.4 \mathrm{mn}$ & 56.10 \\
\hline & & $\mathrm{V}_{3}$ & $1,035 \mathrm{~g}-\mathrm{q}$ & $652 \mathrm{yz}$ & $32 d-g$ & $251 \mathrm{~m}$ & $55 n-v$ & $39 t$ & $2.0 \mathrm{k}-\mathrm{p}$ & $2.0 \mathrm{~h}$ & $55.5 \mathrm{rs}$ & $43.2 \mathrm{y}$ \\
\hline & & $\mathrm{V}_{4}$ & $7820-x$ & 709vwx & $22 \mathrm{~s}-\mathrm{w}$ & $24 \mathrm{mno}$ & $60 j-q$ & $42 \mathrm{~s}$ & $1.9 \mathrm{~m}-\mathrm{r}$ & $1.8 \mathrm{j}$ & 59.3 no & 60.91 \\
\hline & \multirow{4}{*}{$\mathrm{S}_{4}$} & $\mathrm{~V}_{1}$ & $756 r-x$ & 892pqr & $22 \mathrm{~s}-\mathrm{w}$ & 23op & $55 n-v$ & $56 \mathrm{j}$ & $1.9 \mathrm{~m}-\mathrm{r}$ & $1.7 \mathrm{k}$ & $51.6 \mathrm{v}$ & $47.8 \mathrm{w}$ \\
\hline & & $\mathrm{V}_{2}$ & $558 \mathrm{x}$ & $618 z$ & $18 \mathrm{wx}$ & 19rs & $46 u-y$ & $47 \mathrm{qr}$ & $2.0 \mathrm{k}-\mathrm{p}$ & 1.61 & $56.0 \mathrm{qs}$ & $48.8 \mathrm{v}$ \\
\hline & & $\mathrm{V}_{3}$ & 7,860-x & $1,134 \mathrm{ijk}$ & $22 \mathrm{~s}-\mathrm{w}$ & $35 \mathrm{~cd}$ & $530-x$ & $49 n-q$ & $1.9 \mathrm{~m}-\mathrm{r}$ & $1.4 \mathrm{n}$ & $55.3 \mathrm{rs}$ & $51.2 \mathrm{~s}$ \\
\hline & & $\mathrm{V}_{4}$ & $1,165 \mathrm{e}-\mathrm{m}$ & $1,273 \mathrm{f}$ & $28 \mathrm{~h}-\mathrm{o}$ & $32 \mathrm{e}$ & $72 \mathrm{fgh}$ & $65 \mathrm{~h}$ & $2.0 \mathrm{k}-\mathrm{p}$ & $1.3 \mathrm{o}$ & $56.9 \mathrm{qr}$ & $52.7 \mathrm{r}$ \\
\hline \multirow{16}{*}{$\mathrm{WR}_{4}$} & \multirow{4}{*}{$\mathrm{S}_{1}$} & $\mathrm{~V}_{1}$ & $1,047 \mathrm{~g}-\mathrm{o}$ & $1,083 \mathrm{k}$ & $21 u-x$ & $27 \mathrm{jk}$ & $69 \mathrm{f}-\mathrm{j}$ & 7/60i & 1.6 tuv & 1.61 & $52.3 \mathrm{u}$ & $52.0 \mathrm{r}$ \\
\hline & & $\mathrm{V}_{2}$ & $1,037 \mathrm{~g}-\mathrm{p}$ & $884 \mathrm{pqr}$ & $22 \mathrm{~s}-\mathrm{w}$ & $26 \mathrm{kl}$ & $65 \mathrm{~h}-\mathrm{n}$ & $521 \mathrm{~m}$ & $1.7 \mathrm{q}-\mathrm{u}$ & $2.2 \mathrm{f}$ & $54.3 \mathrm{~s}$ & $51.2 \mathrm{~s}$ \\
\hline & & $\mathrm{V}_{3}$ & $892 \mathrm{~m}-\mathrm{v}$ & 799tu & $24 \mathrm{o}-\mathrm{u}$ & $30 \mathrm{fgh}$ & $57 \mathrm{~m}-\mathrm{t}$ & $43 \mathrm{~s}$ & $1.8 \mathrm{o}-\mathrm{t}$ & $2.2 \mathrm{f}$ & $53.6 \mathrm{t}$ & $49.2 \mathrm{u}$ \\
\hline & & $\mathrm{V}_{4}$ & $7890-x$ & $539 \mathrm{yz}$ & $21 u-x$ & $18 \mathrm{~s}$ & 530-x & $39 \mathrm{t}$ & $1.5 \mathrm{uv} 5$ & 1.61 & $55.5 \mathrm{rs}$ & $61.6 \mathrm{k}$ \\
\hline & \multirow{4}{*}{$\mathrm{S}_{2}$} & $\mathrm{~V}_{1}$ & 9161-v & $734 \mathrm{vw}$ & $23 \mathrm{q}-\mathrm{w}$ & $28 \mathrm{ij}$ & $59 \mathrm{k}-\mathrm{r}$ & $42 \mathrm{~s}$ & $1.9 \mathrm{~m}-\mathrm{r}$ & $2.1 \mathrm{~g}$ & $53.2 \mathrm{t}$ & $53.5 \mathrm{q}$ \\
\hline & & $\mathrm{V}_{2}$ & $893 \mathrm{~m}-\mathrm{v}$ & $487 \mathrm{z}$ & 20vwx & $16 \mathrm{t}$ & $60 j-q$ & $43 \mathrm{~s}$ & $1.7 \mathrm{q}-\mathrm{u}$ & $1.2 \mathrm{p}$ & $52.6 \mathrm{u}$ & $54.9 \mathrm{p}$ \\
\hline & & $\mathrm{V}_{3}$ & 736r-x & $947 \mathrm{mno}$ & $23 \mathrm{q}-\mathrm{v}$ & $31 \mathrm{ef}$ & $44 x y z$ & $48 \mathrm{qr}$ & $2.0 \mathrm{k}-\mathrm{p}$ & 1.61 & $48.0 \mathrm{y}$ & $44.6 \mathrm{x}$ \\
\hline & & $\mathrm{V}_{4}$ & $726 r-x$ & $1,123 \mathrm{ijk}$ & $24 \mathrm{o}-\mathrm{u}$ & $27 \mathrm{jk}$ & $46 v-y$ & $65 \mathrm{~h}$ & $1.9 \mathrm{~m}-\mathrm{r}$ & $1.8 \mathrm{j}$ & $45.6 \mathrm{qr}$ & $50.0 \mathrm{t}$ \\
\hline & \multirow{4}{*}{$\mathrm{S}_{3}$} & $\mathrm{~V}_{1}$ & $1,186 \mathrm{~d}-1$ & 861 qrs & $24 \mathrm{o}-\mathrm{u}$ & $26 \mathrm{kl}$ & $67 \mathrm{~h}-1$ & $49 m-q$ & $1.7 \mathrm{q}-\mathrm{u}$ & $1.5 \mathrm{~m}$ & $52.5 \mathrm{u}$ & $51.9 \mathrm{~s}$ \\
\hline & & $\mathrm{V}_{2}$ & $658 \mathrm{u}-\mathrm{x}$ & 898opq & $21 u-x$ & $27 \mathrm{jk}$ & $42 \mathrm{yz}$ & $50 \mathrm{n}-\mathrm{q}$ & $1.80-\mathrm{t}$ & 1.61 & $55.4 \mathrm{r}$ & $51.0 \mathrm{~s}$ \\
\hline & & $\mathrm{V}_{3}$ & $8030-x$ & 685wxy & $23 \mathrm{q}-\mathrm{v}$ & $251 \mathrm{~m}$ & $52 p-y$ & $42 \mathrm{~s}$ & $1.6 \mathrm{tuv}$ & $2.2 \mathrm{f}$ & $50.7 \mathrm{w}$ & $48.3 \mathrm{v}$ \\
\hline & & $\mathrm{V}_{4}$ & $659 u-x$ & $562 \mathrm{yz}$ & $21 u-x$ & $18 \mathrm{~s}$ & $45 w-z$ & $39 t$ & $1.4 \mathrm{vw}$ & $1.9 \mathrm{i}$ & $54.9 \mathrm{~s}$ & $54.9 \mathrm{p}$ \\
\hline & \multirow{4}{*}{$\mathrm{S}_{4}$} & $\mathrm{~V}_{1}$ & $758 \mathrm{q}-\mathrm{x}$ & $538 \mathrm{yz}$ & $23 \mathrm{q}-\mathrm{v}$ & $24 \mathrm{mno}$ & $47 \mathrm{t}-\mathrm{y}$ & $38 \mathrm{t}$ & $1.2 \mathrm{w}$ & $1.2 \mathrm{p}$ & $51.6 \mathrm{v}$ & $49.0 \mathrm{u}$ \\
\hline & & $\mathrm{V}_{2}$ & $653 \mathrm{vwx}$ & $585 \mathrm{yz}$ & $28 \mathrm{~h}-\mathrm{o}$ & $34 d$ & $36 z$ & $30 \mathrm{u}$ & $1.4 \mathrm{vw}$ & 1.61 & $49.2 x$ & $51.7 \mathrm{~s}$ \\
\hline & & $\mathrm{V}_{3}$ & $694 s-x$ & $9901 \mathrm{~m}$ & $22 \mathrm{~s}-\mathrm{w}$ & $27 \mathrm{jk}$ & $44 x y z$ & $56 \mathrm{j}$ & $1.6 \mathrm{tuv}$ & $1.8 \mathrm{j}$ & $50.9 \mathrm{w}$ & $49.7 \mathrm{u}$ \\
\hline & & $\mathrm{V}_{4}$ & 785o-x & 936nop & $27 i-p$ & $21 \mathrm{q}$ & $56 n-u$ & $65 \mathrm{~h}$ & $1.8 \mathrm{o}-\mathrm{t}$ & $1.8 \mathrm{j}$ & $49.7 x$ & $52.3 \mathrm{r}$ \\
\hline
\end{tabular}

of $1 \mathrm{dS} \mathrm{m}^{-1}$ in 2015 and 2016 were 73 and 63, respectively (Table 5). The numbers of pods in 2015 and 2016 in treatment of $80 \%$ water requirement and salinity level of $1 \mathrm{dS} \mathrm{m}^{-1}$ were 94 and 86, respectively (Table 6). The numbers of pods in 2015 and 2016 in Guil cultivar were 66 and 67, respectively, and 67 and 68 in Jonobi cultivar, respectively (Table 7 ). The maximum numbers of pods in treatment of $80 \%$ water requirements and cultivar Guil in 2015 and 2016 were 94 and 86, respectively (Table 8). The number of pods in salinity of $1 \mathrm{dS} \mathrm{m}^{-1}$ in 2015 in the Mesri cultivar was 77, and it was 69 in Guil cultivar in 2016 (Table 9). The numbers of pods in the cultivar Guil and treatment of $100 \%$ water requirement and salinity level of $1 \mathrm{dS} \mathrm{m}^{-1}$ in 2015 and 2016 were 107 and 97, respectively (Table 10). By increasing water stress and salinity, the numbers of pods decreased, since by increasing the osmotic potential in the root zone, water absorption by root decreased [18]. In this situation, due to the loss of pegs and lack of pod formation as well as global warming and stiffness of soil, the peg is not completely formed. In addition, the flowering stage compared to the vegetative growth stage is more sensitive to water stress and salinity, and the effect of high salinity stress on a reduced number of pods is more than water stress effect [8].

\section{Seed Length}

The effects of irrigation; salinity; the interaction of irrigation and salinity; the interaction of salinity and cultivars; combined irrigation, salinity, and cultivars; and irrigation and cultivars are significant (Table 4). See lengths in $100 \%$ water requirement in 2015 and 
Table 11. Production function based on peanut cultivars, water use, and salinity on seed yield.

\begin{tabular}{|c|c|}
\hline 2015 & 2016 \\
\hline$Y_{\text {Guil }}=1,181.065-0.388 w u-22.166 \mathrm{~s}$ & $\mathrm{Y}_{\text {Guil }}=954.465-0.0003397 \mathrm{wu}-5.026 \mathrm{~s}$ \\
\hline $\mathrm{Y}_{\text {Gorgni }}=1,340.383-0.006 \mathrm{wu}-94.155 \mathrm{~s}$ & $\mathrm{Y}_{\text {Gorgni }}=1,061.916-0.0005901 \mathrm{wu}-50.88 \mathrm{~s}$ \\
\hline $\mathrm{Y}_{\text {Jonobi }}=1,335.9-0.006 \mathrm{wu}-76.302 \mathrm{~s}$ & $\mathrm{Y}_{\text {Jonobi }}=1,110.56-0.002 \mathrm{wu}-34.943 \mathrm{~s}$ \\
\hline $\mathrm{Y}_{\text {Mesri }}=949.763-0.008 \mathrm{wu}-4.029 \mathrm{~s}$ & $\mathrm{Y}_{\text {Mesri }}=817.97-0.002 \mathrm{wu}-23.401 \mathrm{~s}$ \\
\hline
\end{tabular}

Y: Seed yield ( $\left.\mathrm{kg} \mathrm{ha}^{-1}\right)$, WU: Water use (mm). S: Salinity $\left(\mathrm{dS} \mathrm{m}^{-1}\right)$.

2016 were 2.4 and $2.1 \mathrm{~cm}$, respectively (Table 5). Seed lengths in 2015 and 2016 in salinity of $3 \mathrm{dS} \mathrm{m}^{-1}$ were 2.4 and $2.1 \mathrm{~cm}$, respectively (Table 5). In reaction of water requirement and salinity treatments in 2015 and 2016, the maximum length in $80 \%$ water requirement and salinity of $3 \mathrm{dS} \mathrm{m}^{-1}$ was 2.8 and $2.7 \mathrm{~cm}$ (Table 6). Seed length in 2015 in Guil and Gorgani cultivars was $2.1 \mathrm{~cm}$ and in 2016 was $2 \mathrm{~cm}$ (Table 7). In 100\% water requirement and in Guil, Gorgani, Mesri, and Jonobi cultivars, the lengths of seeds in 2016 were equal $(2.4$ $\mathrm{cm}$ ) (Table 8). In salinity of $3 \mathrm{dS} \mathrm{m}^{-1}$ in 2015 in Jonobi cultivar and in 2016 in Mesri cultivar, seed lengths were 2.5 and $2.3 \mathrm{~cm}$, respectively (Table 9). Seed length in 2015 in $80 \%$ water requirement with salinity of $3 \mathrm{dS} \mathrm{m}^{-1}$ was $3 \mathrm{~cm}$ in Jonobi cultivar. In 2016, maximum seed length was $2.8 \mathrm{~cm}$ at the salinity level of $3 \mathrm{dS} \mathrm{m}^{-1}$, which is related to Guil, Jonobi, and Mesri cultivars in $100 \%$ water requirement conditions, and Jonobi cultivar in treatment of $80 \%$ water requirement (Table 10). It has been reported that salinity, by increasing the osmotic pressure of soil solution, leads to reduced water absorption and decreased cell differentiation, and thus reduced seed length [18].

\section{Plant Height}

The effect of irrigation on plant height was significant in 2015 and 2016 at probability level of 5\%. Salinity values; the interaction effect of irrigation and cultivars; the combined effects of irrigation, salinity, and cultivars; and the interaction of salinity and cultivars on plant height were significant in 2015 and 2016 at probability level of $1 \%$ (Table 4 ). The highest plant height in $80 \%$ water requirement in 2015 and 2016 was 72.4 and 65.7, respectively (Table 5). The highest plant height at salinity of 1 and $5 \mathrm{dS} \mathrm{m}^{-1}$ in 2015 and 2016 obtained 63.4 and $59.5 \mathrm{~cm}$, respectively (Table 5). Maximum plant heights in 2015 and 2016 in treatment of $80 \%$ water requirement and salinity of 1 and $5 \mathrm{dS} \mathrm{m} \mathrm{m}^{-1}$ were 75.6 and $68.7 \mathrm{~cm}$, and 75.3 and $68.4 \mathrm{~cm}$, respectively (Table 6). Gorgani cultivar in 2015 had the highest plant height $(62.5 \mathrm{~cm})$ (Table 7). Maximum plant heights in 2015 and 2016 were in treatment of $80 \%$ water requirement and in Gorgani cultivar with 74 and $67.2 \mathrm{~cm}$, respectively (Table 8). Gorgani cultivar with salinity tolerance of $3 \mathrm{dS} \mathrm{m}^{-1}$ in 2015 and 2016 had maximum heights of 66.5 and $62.1 \mathrm{~cm}$, respectively (Table 9). Maximum plant heights in the combined effect of irrigation, salinity, and cultivars in $80 \%$ water requirement and with salinity of $3 \mathrm{dS} \mathrm{m}^{-1}$ were seen in Gorgani cultivar in 2015 and 2016 at 71.5 and $64.9 \mathrm{~cm}$, respectively (Table 10). Research demonstrated that a shortage of water by reducing the plant growth rate reduces the height of the plant and increases salinity up to $3 \mathrm{dS} \mathrm{m}^{-1}$, which is directly associated with reduced height, which is consistent with the results of this study [18].

\section{Estimate of Production Function}

The relationship between the value of water used and salinity levels and yield in peanut cultivars is shown in Table 11. With increasing salinity level, yield level decreased significantly and the salinity level of $7 \mathrm{dS} \mathrm{m}^{-1}$, and the highest yield decline was seen in the cultivars. In the regard, the most sensitive cultivar to salinity was Mesri and the most tolerant was Jonobi.

\section{Conclusions}

According to the results of this study, tolerance of peanut cultivars to salinity varied. The highest seed yields in $80 \%$ of water demand management in 2015 and 2016 were, respectively, 1,177 and $1,169 \mathrm{~kg} \mathrm{ha}^{-1}$. The highest seed yields in salinity levels in terms of $1 \mathrm{dS} \mathrm{m}^{-1}$ in 2015 and 2016 were, respectively, 1,142 and $978 \mathrm{~kg} \mathrm{ha}^{-1}$. In the interaction between irrigation and salinity levels, the highest seed yield in $80 \%$ of water and salinity $1 \mathrm{dS} \mathrm{m}^{-1}$ in 2015 and 2016 was, respectively, 1,393 and $1,265 \mathrm{~kg} \mathrm{ha}^{-1}$. The maximum seed yield was in Jonobi cultivar with $1 \mathrm{dS} \mathrm{m}^{-1}$ in salinity and Guil cultivar with $5 \mathrm{dS} \mathrm{m}^{-1}$ in salinity, respectively, at 1,254 and $1,127 \mathrm{~kg} \mathrm{ha}^{-1}$. Guil cultivar in terms of $100 \%$ water requirement and with salinity $1 \mathrm{dS} \mathrm{m}^{-1}$ in 2015 and 2016, respectively, in 1,883 and $1,710 \mathrm{~kg} \mathrm{ha}^{-1}$ had the highest seed yield. Thus, the Guil cultivar is the most suitable cultivar for cultivation in the region.

\section{References}

1. ANINBON C., JOGLOY S., VORASOOT N., PATANOTHAI A., NUCHADOMRONG S., SENAWONG T. Effect of end of season water deficit on phenolic 
compounds in peanut genotypes with different levels of resistance to drought. Food Chemistry. 196, 123, 2016.

2. VOGT T. Phenylpropanoid biosynthesis. Molecular Plant. 3, 2, 2010.

3. VORASOOT N., SONGSRI P., AKKASAENG C., JOGLOY S PATANOTHAI. The Effect of water stress on yield and agronomic characters of peanut (Arachis hypogaea L.). Songklanakarin Journal of Science and Technology. 25 (3), 2838, 2003.

4. ABOU KHEIRA ABDRABBO A. Macromanagement of deficit-irrigated peanut with sprinkler irrigation. Agricultural Water Management. 96, 1409, 2009.

5. BERA S.K., AJAY B.C., SINGH A.L. WRKY and $\mathrm{Na}+$ / $\mathrm{H}+$ anti porter genes conferring tolerance to salinity in interspecific derivatives of peanut (Arachis hypogaea L.). A review. Agronomy for Sustainable Development. AJCS 7 (8), 1173, 2013

6. SONGSRI P., JOGLOY S., HOLBROOK C.C., VORASOOT N., KESMALAT.C., AKKASAENG C., PATANOTHAI A. Association of root, specific leaf area and SPAD chlorophyll meter reading to water use efficiency of peanut under different available soil water. Agricultural Water Management. 96, 790, 2009.

7. KOUSHIK C., BHADURI D., MEENA H.N., KALARIYA K. External Potassium $\left(\mathrm{K}^{+}\right)$Application Improves Salinity Tolerance By Promoting $\mathrm{Na}^{-}$Exclusion, $\mathrm{K}^{+}$Accumulation and Osmotic Adjustment In Contrasting Peanut Cultivars Plant Physiology And Biochemistry 103, 143, 2016.

8. BHAUSO T.D., THANKAPPAN R., KUMAR A., PRAKASH G., MISHRA A., DOBARIA J.R., RAJAM M.V. Over-expression of bacterial mtld gene confers enhanced tolerance to salt-stress and water-deficit stress in transgenic peanut (Arachis hypogaea) through accumulation of mannitol. AJCS 8 (3), 413, 2014.

9. MUSHTAQ S., MOGHADDASI M. Evaluating the potential of deficit irrigation as an adaptive response to climate change and environment demand. Environmental Science and Policy. 14, 1139,. 2011.
10. QIN J., DONG WY, HE K.N., YU Y., TAN G.D., HAN L., DONG M., ZHANG Y.Y., ZHANG D., LI Z.A., WANG Z.L. NaCl Salinity-Induced Changes in Water Status, Ion Contents and Photosynthetic Properties of Shepherdia Argentea (Pursh) Nutt. Seedlings. Plant Soil Environ. 56, 325, 2010.

11. RATNAKUMAR P., RAJENDRUDU G., SWAMY P.M. Photosynthesis and growth responses of peanut (Arachis hypogaea L.) to salinity at elevated $\mathrm{CO}_{2}$. Plant Soil Environ. 59 (9), 410, 2013.

12. SALWA A.R.H., SHABAN K.A., TANTAWY M.F. Studies on salinity tolerance of two peanut cultivars in relation to growth, leaf water content some chemical aspects and yield. Applied sciences research. 6, 1517, 2010.

13. KAUSAR A., ASHRAF M.Y., IFTIKHAR A., NIAZ M., QAISER A. Evaluation of sorghum varieties/lines for salt tolerance using physiological indices as screening tool. Pak J Bot. 44, 47, 2012.

14. DOGAN M., TIPIRDAMAZ R., DEMIR Y. Salt resistance of tomato species grown in sand culture. Plant Soil Environ. 56, 499, 2010.

15. OULD AHMED B.A., INOUE M., MORITANI S. Effect of saline water irrigation and manure application on the available water content, soil salinity and growth of wheat. Agricultural water management. 97, 16, 2010.

16. QIU G.Y., WANG L., HE X., ZHANG X., CHEN S., CHEN J., YANG Y. Water use efficiency and evapotranspiration of winter wheat and its response to irrigation regime in the north China plain. Agric. Forest Meteo. 148, 1848, 2008.

17. MEENA H.N., BHALODIA P.K., JAT R.S., VEKARIA L.C. Prospects of using saline water irrigation in peanut (Arachis hypogaea) pearl millet (Pennisetumglaucum) cropping system in saline black soil of Saurashtra. Indian J. Agron. 57, 9, 2012.

18. SINGH A.L., HARIPRASANNA K., CHAUDHARI V., GOR HK., CHIKANI BM. Identification of groundnut (Arachis hypogaea L.) cultivars tolerant of salinity. J Plant Nutr. 33, 1761, 2010. 